\title{
Flood protection in historical towns
}

\author{
K. Nedvedova \\ Institute of Theoretical and Applied Mechanics, \\ Academy of Science, Czech Republic
}

\begin{abstract}
This contribution discusses some results of the ongoing research focused on the protection of cultural heritage from flood danger. The research project Methodology of Protection and Rescue of Cultural Heritage against Flood takes part in Czech Republic and is focused on specific regional problems that have been experienced during and after disastrous floods in the past 15 years. We would like to show that rivers should be seen not only as a threat but also as a very important space-creating element, life source, connection and border between places. There is great need of an interdisciplinary approach in planning of flood protection systems where not only a technical but also an architectural, cultural, esthetical and historical point of view would be taken into account. We have to have in mind that each field of knowledge has only a limited point of view but urban areas especially with cultural heritage on site are very complex systems that require also a complex approach to solve the flood problem. Otherwise, as we experienced in many case studies, there could be more harm done by a flood protection system than by the flood itself. When a river is cut off from the city it can create a very unnatural environment that ends up in dead places and the decomposition of the former urban structure.
\end{abstract}

Keywords: cultural heritage, flood protection systems, interdisciplinarity, flooding, historic towns.

\section{Introduction}

Flood is one of the natural hazards that cannot be avoided and its control is very limited. Unexpected disastrous events are recently becoming more and more frequent. In the past 20 years, the Czech Republic has experienced quite a few instances of severe flooding and there is now no region that has not been 
influenced by flood risk. Due to climate change it is highly probable that the frequency and importance of those situations is going to be greater.

Although floods are usually short-term events, it takes a very long time and enormous effort to deal with the consequences. Cultural heritage forms special category that requires usually unique and individual approach because its assets cannot be reproduced in contrary to ordinary buildings and objects. Irreversible loss and great expenses spent to restoration and renewal is calling for integrated flood risk management.

\section{Problem analysis}

Protection of cultural heritage from flood damage on the one hand leads towards their better maintenance but on the other hand can often change their character or its surrounding. It is a very difficult task to predict possible losses and gains and evenly balance them. Talking about damage related to flood there are actually three types of them:

- $\quad$ damage by flood itself (Drdácký [1]);

- damage by inappropriate remedial work;

- damage by inappropriate flood protective measures.

The first two points deal mainly with constructions and material substance. An awareness of value of authentic materials and evidence of traditional technology is very important. Effective instructions for owners and administrators of buildings but also for local authorities, what to do before, during, and after the flood, should be easily available (Drdácký et al. [2]). Education about most common mistakes and also good practice is highly necessary (Drdácký and Sližzová [3]). However, in this paper we would like to focus on the last point concerning bigger spatial intervention and causing rather damage of the space.

In the Czech Republic is still advocated approach to solve high water problems through technical measures that offer quick but very one-sided solutions. Measures that positively serve to protect human lives and property can negatively result in damage of space that is part of cultural heritage. Protection that should increase safety and therefore value of the place is degrading its attractiveness by disrupting its structure. The final result is then very questionable. When we increase protection we usually raise also its disturbing effects. It is very hard to find the right balance.

Flood protection systems from their nature are very influential, expensive and invasive constructions. They affect large areas with different variety of users and therefore different interests come in consideration. Urban, architectural, ecological, cultural, technical, financial and other demands are competing with each other and usually are in opposition. 


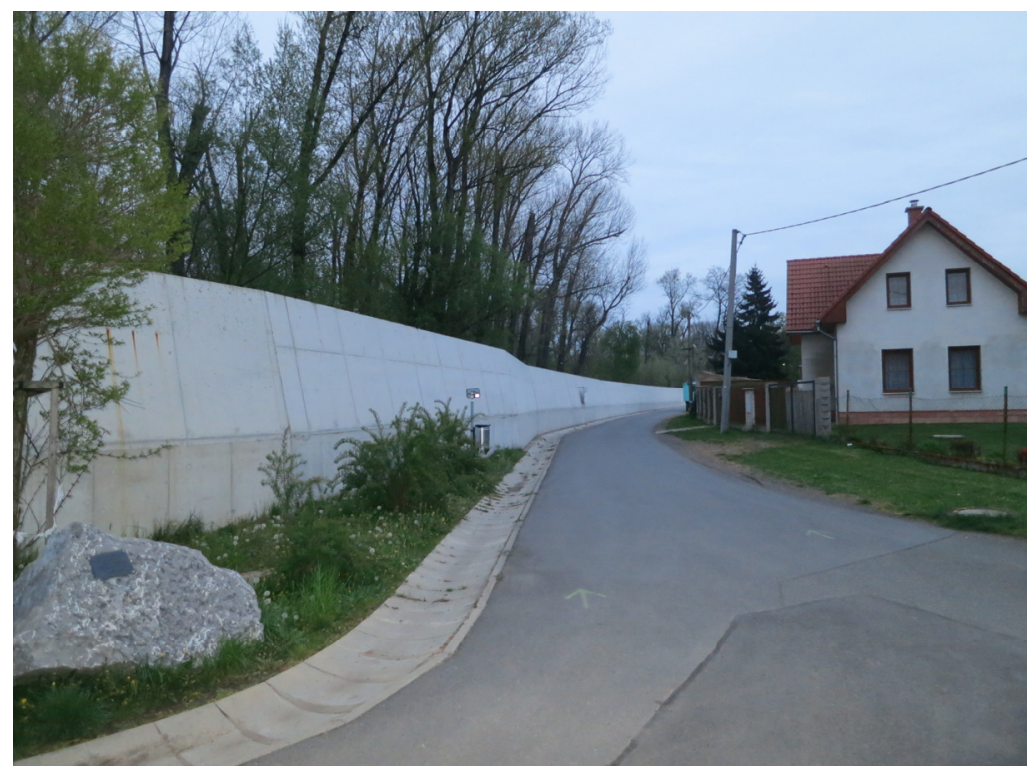

Figure 1: Horrín - a small town upon Elbe - the area in front of the wall. The surrounding area is physically and visually cut off; former connection is interrupted.

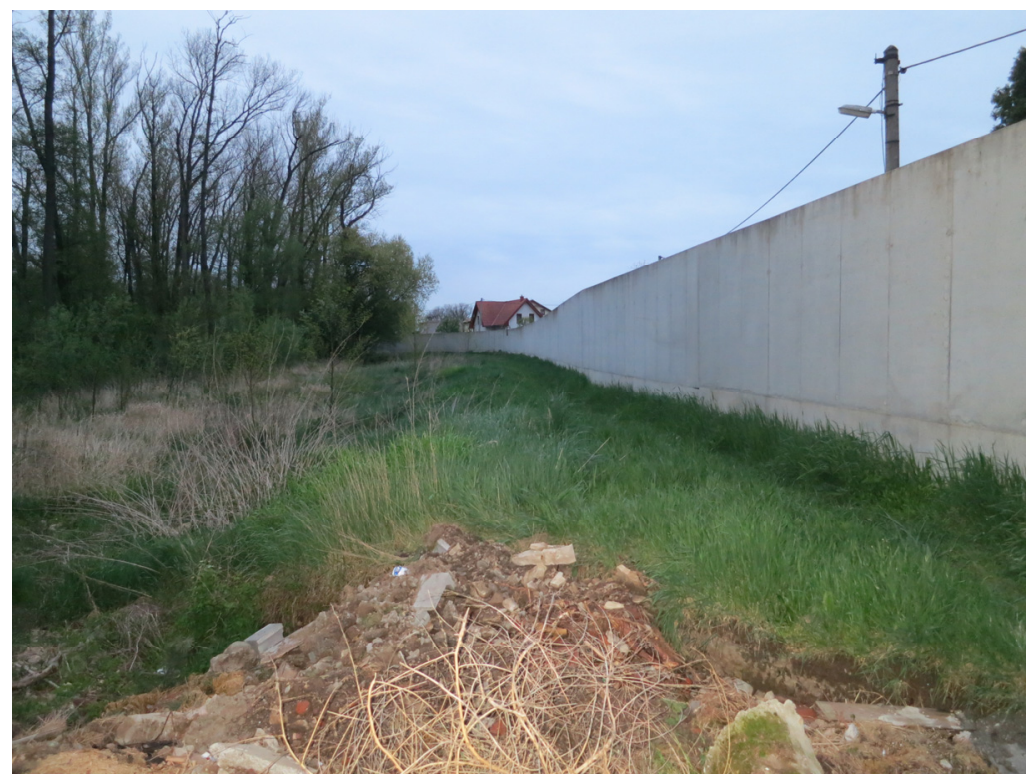

Figure 2: Hořín - small town upon Elbe - the space behind the wall is totally neglected. As access is cut off, the river bank is becoming a no go area. 
During our research we were trying to discover main problem areas that are influencing the planning process and what proved to be helpful to achieve better results. Finally we come up with following:

- interdisciplinary dialog in flood protection planning,

- connection between urban planning and flood protection,

- guidelines for flood protection planning on outstanding cultural heritage sites,

- $\quad$ platform for sharing the experience from already implemented measures - good and bad practice,

- transparency in legislation and processes of flood protection planning to achieve maximal efficiency and sensitivity,

- open public discussion to avoid future disagreement and meet proper needs,

- long term planning considering the maintenance and sustainability of the measures.

It became quite clear that to avoid negative influence of those costly measures all stakeholders should ideally follow the same goal. This needs difficult interdisciplinary negotiation (Nedvědová [4]) and process of integration. In this sense it is a dynamic, process orientated task aimed to protect inherited values and improve safety through innovative protective measures.

\section{Flood protection system planning guide}

Foreknowledge from preliminary research made us think about possible supportive tools that would encourage meeting of all participants in discussion and enable clear orientation in very complex situation where lot of different interests and concerns encounter. The aim is to provide local authorities and planners with effective tool for flood protection system planning that would support integration of this process into the landscape and urban planning. From this point of view idea of software, that should be able to track the whole procedure from the very beginning to the actual realization of the specific construction, emerged. We focus mainly on improvement of cooperation among partial subjects in the planning process and clarifying of their roles (Pergl [5]). Special stress is put on historical sites and urban areas where cultural heritage is forming the identity of the place.

The software solution for optimising project coordination is based on the features of the issue, which is a workflow system [6]. It consists of various participants performing certain roles. Individual participants' actions and states are important for the whole process success. The preliminary analysis shows that communications between participants are of paramount importance. Other features include document storage, timing and deadline characteristics, audit trail and logs.

Together with our IT colleagues we decided to apply the Business Object Relation Modelling method (BORM) (Liping and Roussev [7]) which is a complex method for systems analysis and design that utilizes an object oriented paradigm in combination with business process modelling. This method as such 


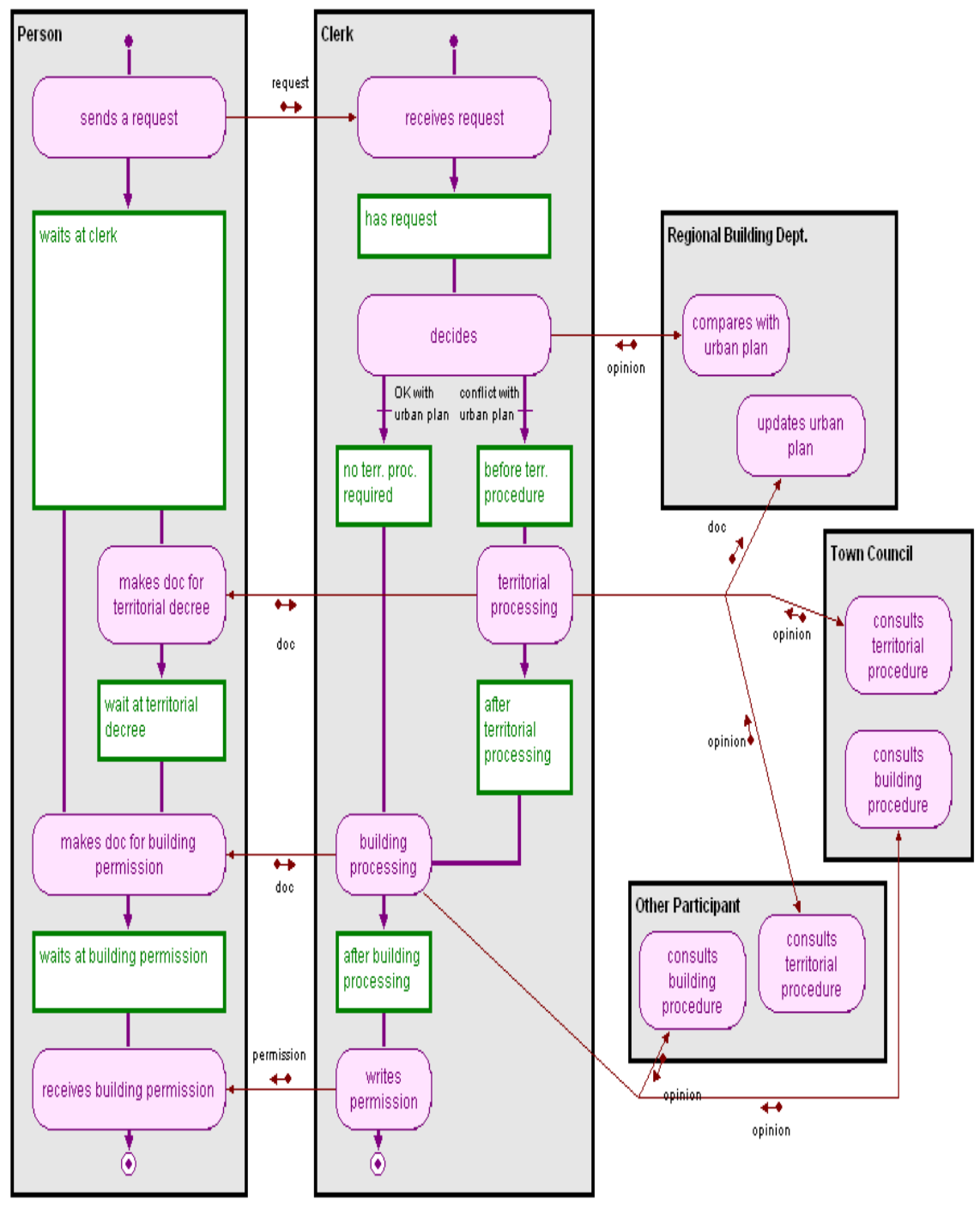

Figure 3: Example of business process as a cooperation of participating objects described by state machines (Merunková [9]).

\section{Acknowledgement}

The research has been supported by the research grant NAKI DF11PO1OVV009 provided by MK ČR. 


\section{References}

[1] Drdácký, M.: Flood Damage to Historic Buildings and Structures. J. Perf. Constr. Fac. Volume 24, Issue 5, pp. 439-445, 2010, http://dx.doi.org /10.1061/(ASCE)CF.1943-5509.0000065.

[2] Drdácký, M., Valach, J., Křemen, P., Abrahamčík, J.: Damage database. In: Cultural Heritage Protection Against Flooding. Prague: Institute of Theoretical and Applied Mechanics Academy of Sciences of the Czech Republic, 2011, p. 185-195. ISBN 978-80-86246-37-6.

[3] Drdácký, M., Sližžková, Z.: Structural strategies and measures reducing flood action on architectural heritage. In "Risk Analysis VIII" (C.A. Brebbia - ed.), ISBN: 978-1-84564-620-2, eISBN: 978-1-84564-621-9, ISSN (print): 1746-4463, ISSN (online): 1743-3517, WIT Transactions on Information and Communication Technologies, Vol 44, WIT Press, Ashurst, Southampton, UK, pp. 249-259, doi:10.2495/RISK120221, 2012.

[4] Nedvědová, K.: Cultural Heritage and Flood - Need of Interdisciplinarity. In Journal of Water Resource and Protection, Vol. 5, No. 4A, April 2013 (Special Issue on Water: Unite and Divide).

[5] Pergl, R. Supporting enterprise IS modelling using ontological analysis. Lecture Notes in Business Information Processing, vol. 88 LNBIP, 2011, pp. 130-144.

[6] http://www.amazon.com/Workflow-Modeling-Improvement-ApplicationDevelopment-ebook/dp/B008O5K65C/ref=sr_1_2?s=books\&ie= UTF8\&qid $=1404804947 \&$ sr $=1-2 \&$ keywords $=$ workflow

[7] Liping, L. and Roussev, B. eds. "The BORM Method: A Third Generation Object-Oriented Methodology." Management of the Object-Oriented Development Process: IGI Global, 2005.

[8] Silver, B.: BPMN Method and Style, 2nd Edition, with BPMN Implementer's Guide: A Structured Approach for Business Process Modeling and Implementation Using BPMN 2.0. Cody-Cassidy Press, 2011.

[9] Merunková, I.: Územní plánování pro zvýšení kvality života ve venkovském prostoru. Dissertation thesis, PEF ČZU in Prague, February 2014 